\title{
Introduction to the biosynthesis and metabolism of prostaglandins
}

\author{
Priscilla J. Piper \\ Ph.D.
}

\begin{abstract}
Department of Pharmacology, Institute of Basic Medical Sciences, Royal College of Surgeons of England
\end{abstract}
THE prostaglandins are a family of lipid-soluble, unsaturated hydroxy acids containing twenty carbon (C) atoms and based on the prostanoic acid skeleton. The $\mathrm{C}$ atoms in the molecule are numbered as shown in Fig. 1.

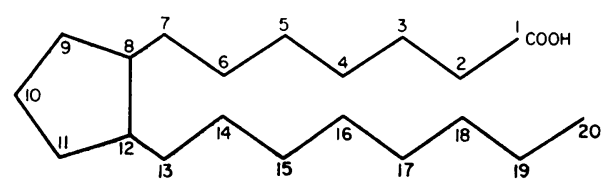

FIG. 1. Prostanoic acid.

The prostaglandins are grouped according to the chemical groups on the pentane ring into types designated by the letters E, F, A, B, C and D. E-type prostaglandins have a ketone group at $\mathrm{C} 9$ and a hydroxyl group at $\mathrm{C} 11$. In D-type prostaglandins these groups are reversed, the ketone being at $\mathrm{C} 11$ and the hydroxyl at C9. F-type prostaglandins have hydroxyl groups at $\mathrm{C} 9$ and $\mathrm{C} 11$ and form isomers designated $\alpha$ and $\beta$, according to the plane of the hydroxyl groups. The A, B and C-type prostaglandins have a ketone group at $C 9$ and 10-11, 11-12 and 8-12 double bonds respectively.

The prostaglandins are also grouped into mono-, bis- or tris-unsaturated classes according to the number of carbon-carbon double bonds in the side chain. The mono-unsaturated prostaglandins have only a 13-14 double bond, the bis-unsaturated have a 5-6 double bond in addition, and the trisunsaturated have a 17-18 double bond also (Andersen, 1971). Prostaglandins E, F, A, B, C, D have a carboxyl group at $\mathrm{Cl}$ and a secondary alcohol group at $\mathbf{C} 15$.

Prostaglandins are not stored in tissues in a preformed state but are synthetized and released in response to a given stimulus (Piper and Vane, 1971). All types of mammalian tissue that have been examined are capable of synthetizing at least a small quantity of prostaglandins. Prostaglandins are synthetized from eicosatrienoic (dihomo- $\gamma$-linolenic), eicosatetraenoic (arachidonic) or eicosapentanoic acids. These compounds are incorporated in phospholipids and are converted to prostaglandins by the action of cyclo-oxygenase (Samuelsson, 1976). This enzyme, previously known as prostaglandin synthetase, is present in the microsomal fraction of cells and initially brings about cyclization and inclusion of molecular oxygen in the precursor. The action of cyclo-oxygenase (and therefore synthesis of prostaglandins) is inhibited by aspirin-like drugs (Vane, 1971; Lands et al., 1974).

In the formation of bis-unsaturated compounds, for example when phospholipids have been hydrolysed by phospholipase A, arachidonic acid is acted on by cyclo-oxygenase or by lipoxygenase (which forms HETE but not prostaglandins). The cyclooxygenase initially stimulates formation of the cyclic-endoperoxides, prostaglandins $\mathrm{G}_{2}$ and $\mathrm{H}_{2}$ (Fig. 2). Prostaglandins $\mathrm{G}_{2}$ and $\mathrm{H}_{2}$ are then converted to either prostaglandins $E_{2}, D_{2}, F_{2 \alpha}$ or thromboxane $\mathbf{A}_{2}$ which is unstable and decays to thromboxane $\mathrm{B}_{2}$; in some tissues, e.g. lung or platelets, the main products of arachidonic acid metabolism are thromboxanes rather than prostaglandins (Hamberg, Svensson and Samuelsson, 1976). Conversion of the endoperoxides to thromboxanes is enzymically controlled by thromboxane synthetase (Needleman et al., 1976). As recently shown by Moncada et al. (1976), when prostaglandins $\mathrm{G}_{2}$ or $\mathrm{H}_{2}$ act on blood vessel walls prostacyclin (prostaglandin $I_{2}$ ) is formed enzymatically. The stable metabolite of prostacyclin is 6-oxoprostaglandin $F_{1 \alpha}$.

The possibility exists for some interconversion of prostaglandins, for example prostaglandin $E_{2}$ may be reduced to prostaglandin $F_{2 \alpha}$ by the action of 9-oxo-reductase which is present in tissues of a number of species (Hensby, 1974). E-type prostaglandins are converted to A-type by acid or alkaline conditions (outside the range $\mathrm{pH}$ 5-8) and A-type rearranges to $B$ in alkaline solution (Andersen, 1971). An isomerase present in plasma of some species converts prostaglandins $\mathrm{A}$ first to prostaglandin $\mathrm{C}$ and then to B (Jones, 1972).

Prostaglandins of the $\mathrm{E}$ and $\mathrm{F}$ series have a short 


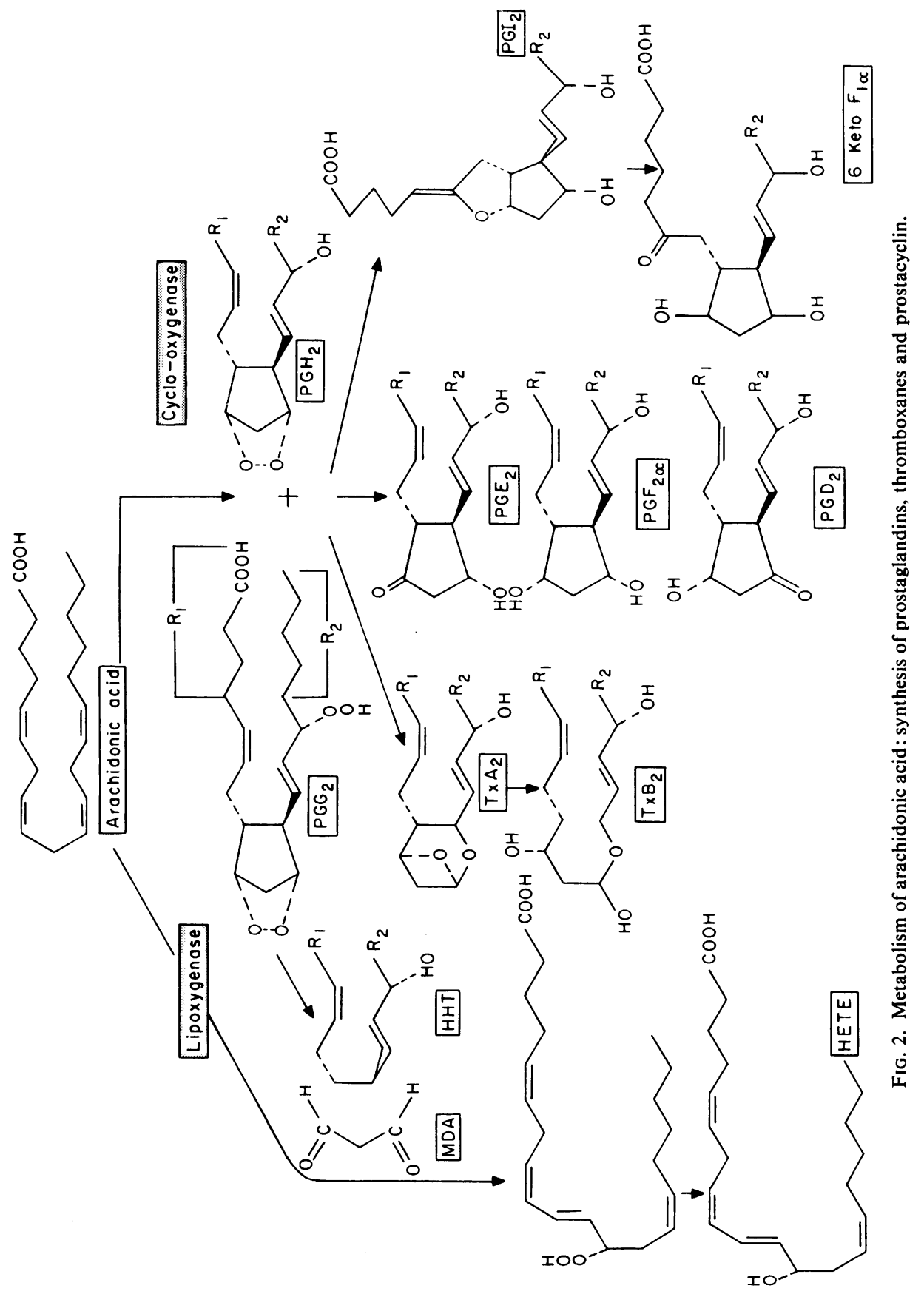




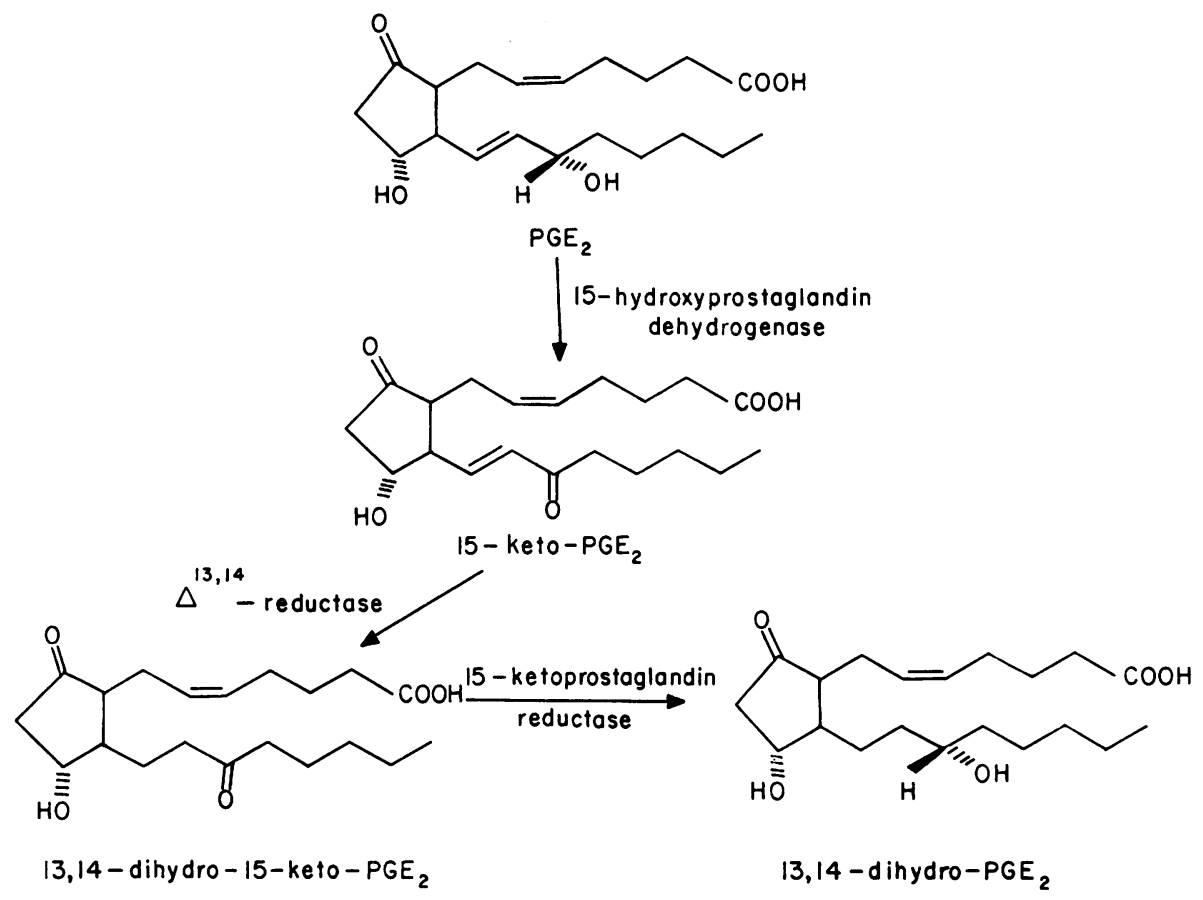

FIG. 3. Metabolism of E- and F-type prostaglandins.

half-life in the circulation and lose up to $95 \%$ of their biological activity on one passage through the pulmonary circulation and are further degraded on passage through other vascular beds (Ferreira and Vane, 1967). Initially the prostaglandins are taken up from the vascular space (Bito, 1975) and then metabolized by a series of enzymes to metabolites which usually have less biological activity than the prostaglandins (Crutchley and Piper, 1975). The enzymes are present in the soluble fraction of cells and are shown in Fig. 3. 15-OH prostaglandin dehydrogenase causes the oxidation of the secondary alcohol group at $\mathrm{C} 15$ which is the rate-limiting step in the breakdown of prostaglandins. A-type prostaglandins are not so rapidly metabolized by prostaglandin dehydrogenase and do not lose activity in the pulmonary circulation but in the hepatic portal circulation (Horton and Jones, 1969). A-type prostaglandins lose activity on conversion to prostaglandin $\mathbf{B}$ which is biologically inactive. The pulmonary metabolites of the prostaglandins are further broken down in the liver and kidney by $\beta$-oxidation to dinor- (eighteen $\mathrm{C}$ atoms) and tetranor- (sixteen $\mathrm{C}$ atoms) derivatives and finally undergo $\beta$-oxidation (Samuelsson et al., 1971). The resulting metabolites are excreted in the urine and are biologically inactive.

\section{References}

ANDERSON, N. (1971) Program notes on structure and nomenclature. Annals of the New York Academy of Sciences, $180,14$.

Bıтo, L.Z. (1975) Are prostaglandins intracellular, transcellular or extracellular autocoids? Prostaglandins, 9, 851 .

Crutchley, D.J. \& Piper, Priscilla J. (1975) Comparative bioassay of the pulmonary metabolites of prostaglandin $\mathrm{E}_{2}$. British Journal of Pharmacology, 54, 397.

Ferreira, S.H. \& VANE, J.R. (1967) Prostaglandins. Their disappearance from and release into the circulation. Nature. London, 216, 868.

Hamberg, M., Svensson, J. \& Samuelsson, B. (1976) Novel transformations of prostaglandin endoperoxides: formation of thromboxanes. In: Advances in Prostaglandin and Thromboxane Research, pp. 19-27 (Ed. by B. Samuelsson and R. Paoletti). Raven Press, New York.

HensBY, C.N. (1974) Reduction of prostaglandin $E_{2}$ to prostaglandin $F_{2 \alpha}$ by an enzyme in sheep blood. Biochimica et biophysica acta, 348, 145.

Horton, E.W. \& Jones, R.L. (1969) Prostaglandins $A_{1}, A_{2}$ and 19-hydroxy $A$; their actions on smooth muscle and their inactivation on passage through the pulmonary and hepatic portal vascular beds. British Journal of Pharmacology, 37, 705 .

JoNES, R.L. (1972) The properties of a new prostaglandin. British Journal of Pharmacology, 45, 144.

Lands, W.E.M., Le Tellier, P.R., Rome, L. \& Vanderhoek, J.Y. (1974) Regulation of prostaglandin synthesis. In: Prostaglandin Synthetase Inhibitors, pp. 1-7 (Ed. by H. J. Robinson and J. R. Vane). Raven Press, New York.

Moncada, S., Gryglewski, R., Bunting, S. \& Vane, J.R. (1976) An enzyme isolated from arteries transforms 
prostaglandin endoperoxides to an unstable substance that inhibits platelet aggregation. Nature. London, 263, 663.

Needleman, P., Moncada, S., Bunting, S., Vane, J.R., HAMBerg, M. \& SAMUelsson, B. (1976) Identification of an enzyme in platelet microsomes which generates thromboxane $\mathrm{A}_{2}$ from prostaglandin endoperoxides. Nature. London, 261, 558.

Piper, Priscilla, J. \& VANe J.R. (1971) The release of prostaglandins from lung and other tissues. Annals of the New York Academy of Sciences, 180, 365.
SAMUELSSON, B. (1976) New trends in prostaglandin research. In: Advances in Prostaglandin and Thromboxane Research, pp. 1-6 (Ed. by B. Samuelsson and R. Paoletti). Raven Press, New York.

Samuelsson, B., Granström, E., Green, K. \& Hamberg, M. (1971) Metabolism of prostaglandins. Annals of the New York Academy of Sciences, 180, 138.

VANE, J.R. (1971) Inhibition of prostaglandin synthesis as a mechanism of action for aspirin-like drugs. Nature, New Biology, 231, 232. 